\title{
Effect of Adjunct Culture Lactobacillus helveticus (B02) on the Composition, Proteolysis, Free Amino Acids Release and Sensory Characteristics of Prato Cheese
}

\author{
Natália Chinellato de Azambuja1, Izildinha Moreno², Darlila Aparecida Gallina², \\ Leila Maria Spadoti², Eliana Maria Pettirossi Motta ${ }^{3}$, Maria Teresa Bertolodo Pacheco", \\ Angela Lima Menêses de Queiroz ${ }^{5}$, Adriane Elisabete Costa Antunes ${ }^{{ }^{*}}$

\footnotetext{
${ }^{1}$ Faculdade de Ciências Aplicadas, Universidade Estadual de Campinas (FCA/UNICAMP), Limeira, Brazil ${ }^{2}$ Centro de Tecnologia de Laticínios, Instituto de Tecnologia de Alimentos (TECNOLAT/ITAL), Campinas, Brazil ${ }^{3}$ Faculdade de Engenharia de Alimentos, Universidade Estadual de Campinas (FEA/UNICAMP), Campinas, Brazil ${ }^{4}$ Centro de Ciência e Qualidade de Alimentos, Instituto de Tecnologia de Alimentos (CCQA/ITAL), Campinas, Brazil ${ }^{5}$ Centro de Tecnologia, Universidade Federal da Paraíba, João Pessoa, Brazil Email: *adriane.antunes@fca.unicamp.br
}

How to cite this paper: de Azambuja, N.C., Moreno, I., Gallina, D.A., Spadoti, L.M., Motta, E.M.P., Pacheco, M.T.B., de Queiroz, A.L.M. and Antunes, A.E.C. (2017) Effect of Adjunct Culture Lactobacillus helveticus (B02) on the Composition, Proteolysis, Free Amino Acids Release and Sensory Characteristics of Prato Cheese. Food and Nutrition Sciences, 8, 512-525. https://doi.org/10.4236/fns.2017.85035

Received: March 16, 2017

Accepted: May 14, 2017

Published: May 17, 2017

Copyright $(9) 2017$ by authors and Scientific Research Publishing Inc. This work is licensed under the Creative Commons Attribution International License (CC BY 4.0). http://creativecommons.org/licenses/by/4.0/

\begin{abstract}
At semi-industrial scale it was obtained two cheeses, one with aromatic culture $(\mathrm{CHN})$ and the other with also L. helveticus $(\mathrm{CHN}+\mathrm{LH})$. Proteolysis during ripening was evaluated using proteolytic indices, electrophoretic profile Urea-PAGE and release of free amino acids. Sensory evaluation was performed by acceptability test. It was observed a 5-fold increase in the fraction corresponding to $\alpha_{\mathrm{s} 1 \mathrm{I}}$-casein in the $\mathrm{CHN}$ cheese and 6.5 times in the $\mathrm{CHN}+$ LH cheese and 7.2 and 8.2 increase respectively, for total amino acids. Prato cheese with the adjunct culture showed higher acceptability in terms of overall aroma and flavor.
\end{abstract}

\section{Keywords}

Amino Acids, Cheese, L. helveticus, Ripening, Sensory Analysis

\section{Introduction}

Prato is a typical Brazilian cheese that ranks among the most produced cheeses in the country. This type of cheese is of Danish origin, similar to Gouda and Danbo, despite its different flavor and texture [1]. Its industrial process involves enzymatic coagulation of pasteurized cow's milk by the action of rennet enzymes, with the addition of lactic ferment, calcium chloride and a small 
amount of annatto dye (Bixa orellana) to give the characteristic yellow tint [2]. The distinctive characteristics of the manufacturing process are: semi-cooked and delactosed curd obtained at $40^{\circ} \mathrm{C}$, by slowly replacing part of the whey ( $15 \%$ to $20 \%$ of the initial milk volume) with water at $74^{\circ} \mathrm{C}$ to $80^{\circ} \mathrm{C}$ directly on the curd to raise the temperature to no more than $1^{\circ} \mathrm{C}$ per minute. According to legal aspects, the ripening time of the Prato-type cheese must be at least 25 days [2].

According to Kabelová et al. [3], proteolysis contributes to the textural changes of the cheese matrix, due to the breakdown of the protein network, decrease of water activity through water binding by the liberated carboxyl and amino groups, and increase in $\mathrm{pH}$ which facilitates the release of sapid compounds during mastication.

Cheese taste and texture have strong influence depending on the types of cultures used. During cheese ripening, proteolysis of casein forms the basis for generating a wide range of peptides and amino acids, with the potential to influence cheese taste [4]. The acidifying mesophilic cultures Lactococcus lactis ssp. cremoris and Lc. lactis ssp. lactis have been the most widely used in Prato cheese for snacks, sandwiches and other culinary dishes. This culture provides closed textured characteristics, little proteolysis and mild flavor, the most suitable for this purpose.

The CHN culture is composed of Lactococcus lactis ssp. cremoris and Lc. lactis ssp. lactis, and two cultures that promote flavor: Lc. lactis ssp. lactis biovar. diacetylactis and Leuconostoc mesenteroides ssp. cremoris. Besides lactic acid, Lc. lactis ssp. lactis biovar. diacetylactis produces acetoin and diacetyl compounds that provide aroma. Leuconostoc mesenteroides ssp. cremoris is heterofermentative, producing from glucose many compounds: lactic and acetic acids, ethanol, carbon dioxide, acetoin and diacetyl [5]. The cheese produced by this $\mathrm{CHN}$ culture has consistency and buttery features, mild flavor (sweet, not acid and not spicy), oval-shape and shiny eyes [6]. Besides cheese, CHN culture can be used to obtain fermented buttermilk, promoting a buttery flavor, and a sense of spiciness and effervescence to this product [7] [8].

Lactobacillus helveticus ( $\mathrm{LH})$ is a thermophilic homofermentative species traditionally used as starter in the manufacture of long ripening Swiss-type cheese, Italian cheese, such as Emmental, Gruyere, Grana Padano and Parmigiano Reggiano and fermented milk beverages [9] [10]. LH strains have been used as adjunct cultures for other cheese types in order to accelerate ripening, for the degradation of hydrophobic peptides, to reduce the bitter taste and to enhance flavor notes [11] [12]. LH has also been considered a health promoting culture due to its potential for producing bioactive peptides and bacteriocins, and for exerting symbiotic effect when combined with probiotics in fermented milk products [10]. Some peptides formed from proteolysis have antihypertensive, antimicrobial and antioxidant biological properties, which add value to the product [13] [14]. The proteolytic system of LH is very efficient. It consists of cellenvelope proteases (CEP) for initial casein hydrolysis for oligopeptides and ami- 
no acids; various intracellular peptidases for subsequent oligopeptides hydrolysis of small peptides and amino acids; and specific carriers for oligopeptides, tripeptides, dipeptides and free amino acids released from casein [9] [11].

The objective of this study was to evaluate the potential of using L. helveticus B02 as an adjunct culture of mesophilic aromatic culture to improve Prato cheese ripening and sensory characteristics.

\section{Material and Methods}

\subsection{Culture Preparation}

Mesophilic aromatic culture CHN-22 DVS (direct vat set) presently referred as $\mathrm{CHN}$, and thermophilic culture Lactobacillus helveticus B02 DVS (LH culture) from Chr. Hansen (Valinhos, SP, Brazil) were rehydrated in $1 \mathrm{~L}$ of sterilized $\left(110^{\circ} \mathrm{C}\right.$ for $\left.10 \mathrm{~min}\right)$, reconstituted $(10 \%, \mathrm{w} / \mathrm{v})$ powder skimmed milk (Molico, Nestle). Prior to manufacturing the cheese, the CHN culture was activated (growth at $22^{\circ} \mathrm{C}$ for $16 \mathrm{~h}$ ) and the $\mathrm{LH}$ culture activated at $45^{\circ} \mathrm{C}$ for $18 \mathrm{~h}$.

\subsection{Cheese Manufacturing}

Two batches of cheese were produced in parallel using $140 \mathrm{~L}$ of milk for each batch, at semi-industrial scale, using a $200 \mathrm{~L}$ capacity Queijomatic tank (Biasi-

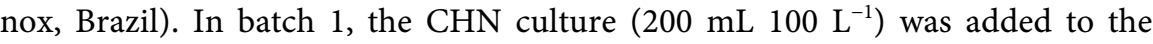
pasteurized milk. In the 2 nd batch, besides the addition to the CHN culture, the LH culture was added $\left(215 \mathrm{~mL} 100 \mathrm{~L}^{-1}\right)$ after coagulation, according to the flowchart of Prato cheese processing (Figure 1). The following technological coadjuvants were employed: annato dye $\left(5 \mathrm{~mL} 100 \mathrm{~L}^{-1}\right.$, Chr. Hansen, Brazil), calcium chloride solution $40 \%\left(60 \mathrm{~mL} 100 \mathrm{~L}^{-1}\right.$, Synth, Brazil) and rennet liquid CHY-MAX (7 mL $100 \mathrm{~L}^{-1}, 35 \mathrm{~min}$ coagulation, Chr. Hansen, Brazil). Heatshrinkable plastic packaging was used for packaging the cheeses using a Selovac vacuum sealer (Supervac, GK185, Brazil).

\subsection{Physicochemical Composition of Milk and Prato Cheese}

Heat-treated milk was characterized for $\mathrm{pH}$ ( $\mathrm{pH}$ meter Micronal B-375), titratable acidity (\%lactic acid), and fat using the Gerber method [16], total dry matter [17], lactose [18], salt [19], ash [20] and total nitrogen (TN), using the Kjeldahl method (Conversion factor 6.38) [16] [21] [22].

After three days manufacturing and 10,17, 24 31, 38 and 45 days of ripening the cheeses were analyzed for $\mathrm{pH}$, titratable acidity and fat moisture, lactose, salt, ashes, total nitrogen, soluble nitrogen at $\mathrm{pH} 4.6$ [23] and soluble nitrogen in $12 \%$ TCA [16] [21] [24], using the Kjeldahl method (Conversion factor 6,38). Three pieces of cheese from each treatment ( $\mathrm{CHN}+\mathrm{LH}$ cheese and CHN cheese) were randomly chosen. The analyses were performed in triplicate and the results were analyzed statistically using the Statsoft Statistic $5.0^{\circ}$ software.

\subsection{Microbiological Quality of the Milk and Cheese}

The pasteurized milk was analyzed for Salmonella sp. (in $25 \mathrm{~g}$ ), Listeria mono- 


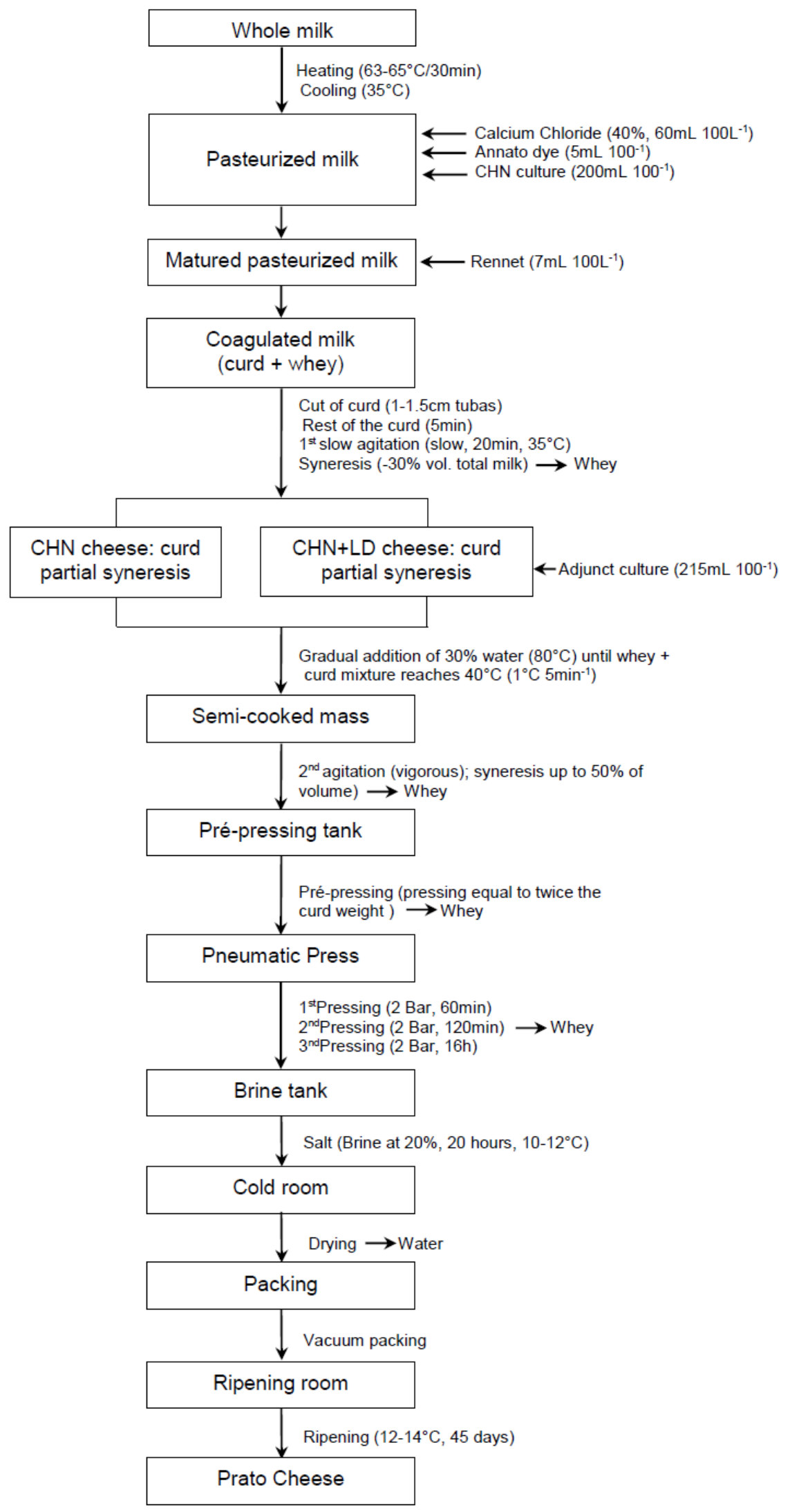

Figure 1. General flowchart of Prato cheese processing of according to Furtado and Lorenzo [15], with modifications. 
cytogenes (in $25 \mathrm{~g}$ ), coagulase-positive staphylococci $\left(\mathrm{CFU} \mathrm{g}{ }^{-1}\right)$, total mesophilic $\left(\mathrm{CFU} \mathrm{g}{ }^{-1}\right)$, mold and yeasts $\left(\mathrm{CFU} \mathrm{g} \mathrm{g}^{-1}\right)$, coliforms at $35^{\circ} \mathrm{C}$ and $45^{\circ} \mathrm{C}\left(\mathrm{MPN} \mathrm{g}^{-1}\right)$ [21]. Cheeses were analyzed for the same microorganisms except for total mesophilic bacteria.

\subsection{Characterization of Proteolysis during Ripening}

Cheese at 3 days following manufacture and at 10, 17, 24 31, 38 and 45 days of ripening were analyzed for proteolysis and electrophoretic profile of casein and at 3, 24 and 45 days for release of total and individual free amino acids.

Proteolysis was determined as soluble nitrogen at $\mathrm{pH}$ 4.6, expressed as a percentage of total nitrogen (Extension Index of Proteolysis-EIP), and as soluble nitrogen in trichloroacetic acid 12\%, expressed as a percentage of total nitrogen (Depth of Proteolysis Index-DPI), determined by the macro-Kjeldahl method [23] [24] [25].

Polyacrylamide gel electrophoresis (urea-PAGE) was carried out using a vertical mini-PROTEAN ${ }^{\bullet}$ Casting System (Bio-Rad Laboratories Inc.), according to Andrews [26]. Briefly, the extracts for electrophoresis were prepared by dissolving $0.01 \mathrm{~g}$ of cheese sample (equivalent to $0.4 \%$ protein). $10 \mu \mathrm{L}$ was applied to the gels. The bands separation was performed at $120 \mathrm{~V}$. The bands were stained overnight by soaking the gels in Bio-Safe Coomassie G-250 Stain (Bio-Rad Laboratories Inc.) and distained with distilled water. Quantification of the casein fraction (relative $\%$ of peak area) was performed using ImageJ software.

Free amino acids were determined by reverse phase-high performance liquid chromatography (RP-HPLC) using a Shimadzu HPLC system (Shimadzu Corporation, Japan), equipped with a Luna/Phenomenex C18 column (4.6 - 250 $\mathrm{mm}, 5 \mathrm{~L}$ ). Identification and quantification was done by external standard (Pierce/PN 20088) with UV detection at $254 \mathrm{~nm}$ [27] [28]. Free amino acids were extracted from $1 \mathrm{~g}$ of the sample with $0.1 \mathrm{M} \mathrm{HCl}$, 99.9\% methanol (30:60) and the addition of internal standard alpha aminobutyric acid $(10 \mathrm{~mL})$, stirred for $1 / 2$ hour using an orbital shaker at $1500 \mathrm{rpm}$.

\subsection{Sensory Analysis}

Acceptability tests were conducted at 7 and 30 days of manufacture with 100 cheese consumers, without restrictions to age, gender or social class. Three samples were presented: Prato cheese (made only with $\mathrm{CHN}$ starter culture), Prato cheese with adjunct culture $(\mathrm{CHN}+\mathrm{LH})$ and commercial Prato cheese (a market leader). The samples were served in a sequential monadic manner according to a complete balanced block design. The samples were evaluated according to Meilgaard et al. [29], for overall acceptability and in particular appearance, aroma, texture and flavor using a nine-point hedonic scale $(9=$ liked it very much, 5 $=$ neither liked or disliked, and $1=$ disliked very much). The test was conducted in individual cabins with fluorescent lamps and equipped with computerized Compusense Five, version 5.4, for data collection and analysis. The results of the sensory analysis were compared using analysis of variance and the Tukey test at 
a significance level of $95 \%(P \leq 0.05)$ using the Fizz Sensory Software program version 2.47B, Fizz Calculation module. The effect of ripening time on color intensity, aroma, smoothness, characteristic Prato cheese taste, salty taste, acidic taste and sour taste was compared using the statistical test using the Excel program [29]. The research was approved by the Research Ethics Committee from FCM/UNICAMP (112.204/Campinas/Brazil).

\section{Results and Discussion}

\subsection{Physicochemical and Microbiological Characterization of Pasteurized Milk and Prato Cheese}

The microbiological and physicochemical results of the milk after pasteurization was in accordance with the Brazilian legislation parameters [30], according to Table 1.

The composition of $\mathrm{CHN}$ and $\mathrm{CHN}+\mathrm{LH}$ cheeses at 3 days following manufacture also complies with the legal parameters established by Brazilian regulations for moisture $(36.0 \%-45.9 \%)$, fat on a dry basis $(45.0 \%-59.9 \%)$ and $\mathrm{pH}$ (5.2 - 5.4) [2], and also with previously published data [31]. The CHN and CHN $+\mathrm{LH}$ cheeses presented similar quantities of proteins, fat, acidity and $\mathrm{pH}$. The addition of the adjunct LH culture after the partial syneresis step of Prato cheese production had no negative effect on the composition of $\mathrm{CHN}+\mathrm{LH}$ cheese regarding the parameters presented above.

Microbiological characterization of $\mathrm{CHN}$ and $\mathrm{CHN}+\mathrm{LH}$ cheeses three days following production (Table 1) complies with the Brazilian legal regulations [32] that establishes absence of Salmonella and Listeria monocytogenes in $25 \mathrm{~g}$ and maximum counts of $5 \times 10^{3} \mathrm{MPN} \mathrm{g}^{-1}$ for coliforms at $30^{\circ} \mathrm{C} ; 5 \times 10^{2} \mathrm{MPN} \mathrm{g}^{-1}$ for coliforms at $45^{\circ} \mathrm{C} ; 1 \times 10^{3} \mathrm{CFU} \mathrm{g}^{-1}$ for Staphylococcus coagulase positive. Therefore, the hygienic-sanitary measures applied during processing were sufficient to achieve quality and safety.

\subsection{Characterization of Proteolysis during Ripening}

Proteolysis during cheese ripening was determined by the concentration (\%) of the soluble nitrogen compounds at $\mathrm{pH} 4.6-\mathrm{SN}$ at $\mathrm{pH} 4.6$ (extension of proteolysis) and SN 12\% TCA (depth of proteolysis) related to the percentage of total nitrogen (TN), as shown in Figure 2, letters A and B, respectively. We observed for both $\mathrm{CHN}$ and $\mathrm{CHN}+\mathrm{LH}$ cheeses a gradual increase of the Extension Index of Proteolysis (EIP) and Depth of Proteolysis Index (DPI), with 45 days of ripening time. The EIP represents the high molecular weight peptides which are released during casein hydrolysis. In the first weeks of ripening, proteolysis is due to milk proteases (especially plasmin), residual activity of the rennet, native proteinases and, to a lesser extent, to proteinases of lactic cultures and nonstarter lactic acid bacteria [33]. A secondary proteolysis is represented by small peptides and free amino acids formed during ripening, mainly due to the action of proteases and peptidases in the nitrogenous compounds released from the casein hydrolysis. Small peptides and free amino acids contribute to the sensory 
Table 1. Physical-chemical and microbiological characterization and viability of CHN and $\mathrm{CHN}+\mathrm{LH}$ cultures in Prato cheese three days after production.

\begin{tabular}{|c|c|c|}
\hline Parameter & LD Prato Cheese & LD+LH Prato Cheese \\
\hline \multicolumn{3}{|l|}{ Physico-chemical } \\
\hline $\mathrm{pH}$ & $5.36^{\mathrm{a}}$ & $5.40^{\mathrm{a}}$ \\
\hline Acidity (\%) & $0.6^{\mathrm{a}}$ & $0.61^{\mathrm{a}}$ \\
\hline Fat $(\%)$ & $29.39^{\mathrm{a}}$ & $29.05^{\mathrm{a}}$ \\
\hline Fat on a dry basis (\%) & $53.01^{\mathrm{a}}$ & $49.12^{\mathrm{a}}$ \\
\hline Moisture (\%) & $44.56^{\mathrm{a}}$ & $40.86^{\mathrm{b}}$ \\
\hline Salt (\%) & $2.39^{\mathrm{a}}$ & $2.27^{\mathrm{b}}$ \\
\hline Salt humidity (\%) & $5.67^{\mathrm{a}}$ & $5.04^{\mathrm{a}}$ \\
\hline Total protein (\%) & $26.33^{\mathrm{a}}$ & $26.51^{\mathrm{a}}$ \\
\hline \multicolumn{3}{|l|}{ Microbiological } \\
\hline Salmonella sp. (in $25 \mathrm{~g}$ ) & Abs. & Abs. \\
\hline Listeria monocytogenes (in $25 \mathrm{~g}$ ) & Abs. & Abs. \\
\hline Coagulase-positive staphylococci $\left(\mathrm{CFU} \mathrm{g}^{-1}\right)$ & $<10$ & $<10$ \\
\hline Coliforms at $30^{\circ} \mathrm{C}-35^{\circ} \mathrm{C}\left(\mathrm{MPN} \mathrm{g}^{-1}\right)$ & $<3$ & $<3$ \\
\hline Coliforms at $45^{\circ} \mathrm{C}\left(\mathrm{MPN} \mathrm{g}^{-1}\right)$ & $<3$ & $<3$ \\
\hline Molds and yeasts $\left(\mathrm{CFU} \mathrm{g} \mathrm{g}^{-1}\right)$ & $<10$ & $<10$ \\
\hline
\end{tabular}

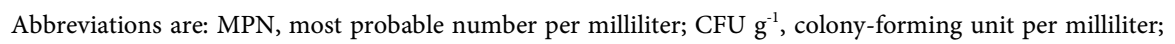
Abs., Absent.

characteristics of Prato cheese [33]. Published data show that the use of L. helveticus as adjunct culture in Prato cheese significantly increased the levels of DPI [34] [35] [36]. There were no significant differences in DPI nor EIP between the $\mathrm{CHN}$ and $\mathrm{CHN}+\mathrm{LH}$ cheeses in this research. However, according to Figure 2(a) (EIP) and Figure 2(b) (DPI), the columns for each treatment started to split after 31 days of ripening and this tendency increased after 45 days of ripening for DPI.

The electrophoretic profile (Figure 3 ) of the cheeses samples shows an increase in the hydrolysis of the $\alpha_{s 1}$-casein fraction due to the action of rennet, clearly showing a higher intensity band corresponding to $\alpha_{\mathrm{s} 1-\mathrm{I}}$-casein, a polypeptide of high molecular weight, acidic and with slightly greater electrophoretic mobility than the $\alpha_{s 1}$-casein.

At 45 days of ripening, the \% of the relative peak area from the electrophoretograms (not shown) we observed degradation of $56 \%$ and $67 \%$ of $\alpha_{s 1}$-casein fraction in the $\mathrm{CHN}$ and $\mathrm{CHN}+\mathrm{LH}$ cheeses, respectively. The values found were very close to those found by Gorostiza et al. [37], which observed $65 \%$ of hydrolysis of $\alpha_{\mathrm{S} 1}$-casein after 60 days of ripening. It was also observed that the corresponding fraction of $\alpha_{s 1-\mathrm{I}}$-casein increased 5 times in CHN cheese and 6.5 times in $\mathrm{CHN}$ and $\mathrm{CHN}+\mathrm{LH}$ cheese, and that the degradation process of the $\alpha_{\mathrm{s} 1}$-casein fraction intensified at 31 days of ripening due to the presence of the adjunct culture. The degradation of $\beta$-casein was small, but it was mainly due to the presence of the adjunct culture, since L. helveticus has the potential to hydrolyze 


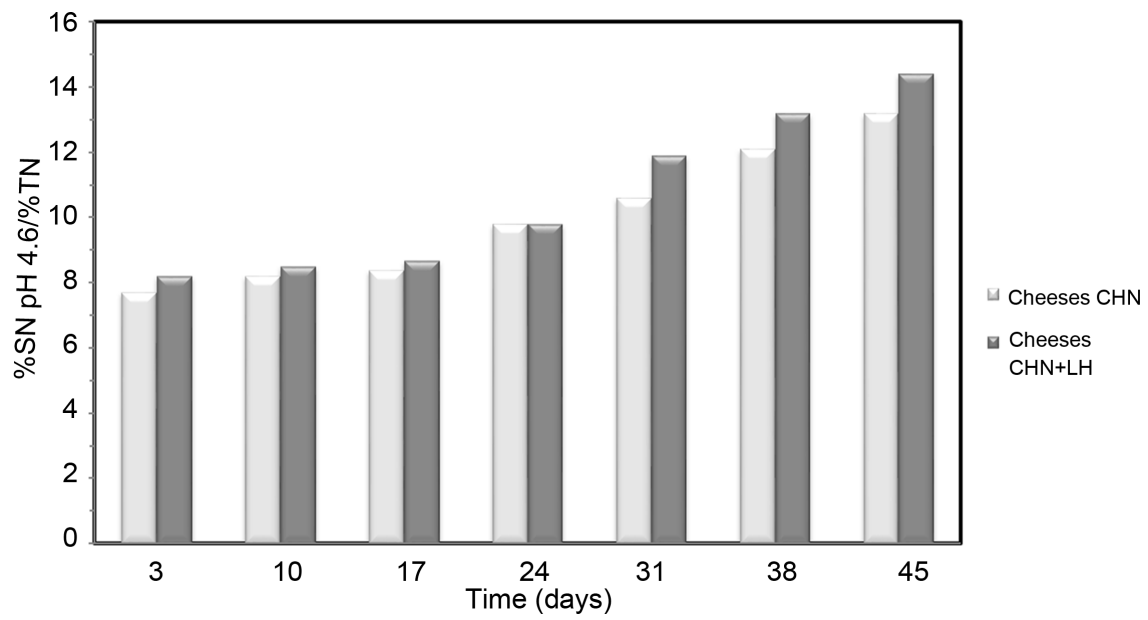

(a)

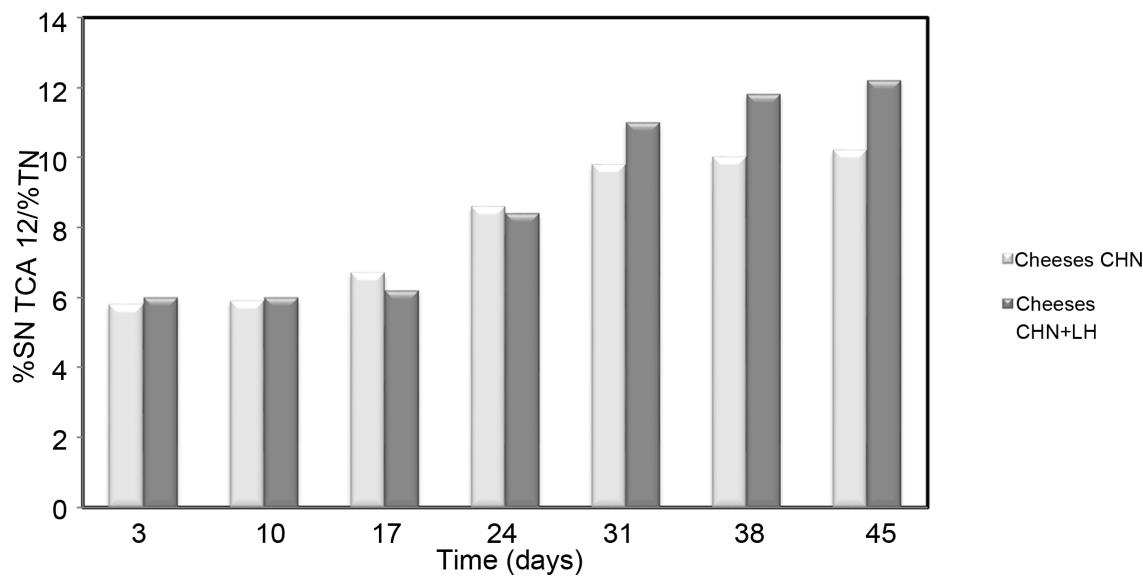

(b)

Figure 2. Extension index of proteolysis-EIP (a) and Depth of Proteolysis Index-DPI (b) in the $\mathrm{CHN}$ and $\mathrm{CHN}+\mathrm{LH}$ cheeses during the 45 days of ripening period at $12^{\circ} \mathrm{C} \pm 2{ }^{\circ} \mathrm{C}$ (CHN-Aromatic mesophilic culture $\mathrm{CHN}-22$; $\mathrm{LH}-$ L. helveticus $\mathrm{B} 02$; $\mathrm{SN}-$ Soluble Nitrogen; TN-Total Nitrogen; TCA—trichloroacetic acid).

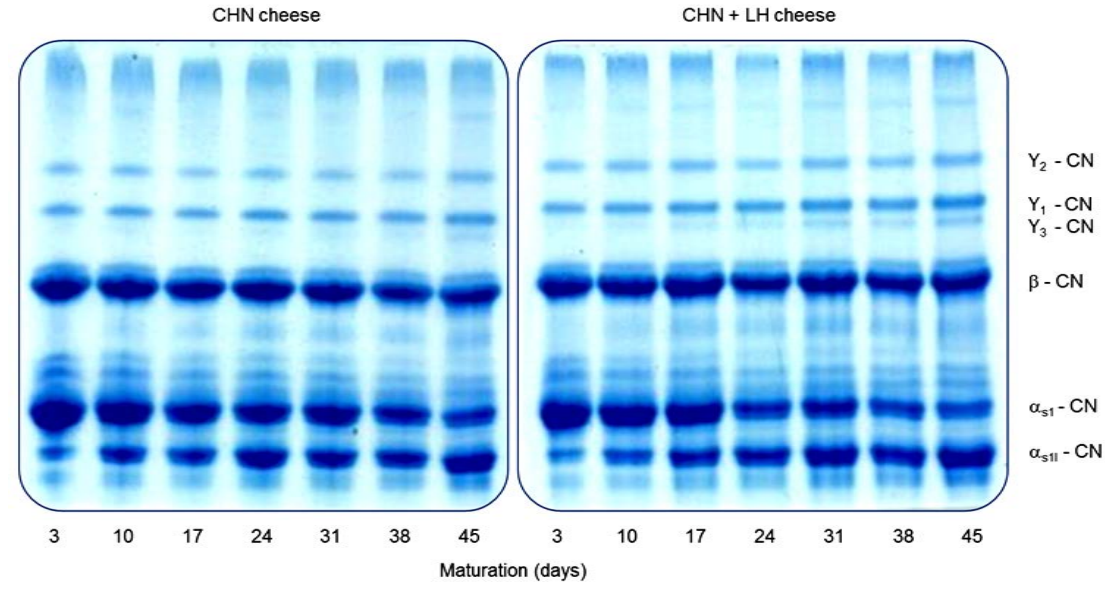

(a)

(b)

Figure 3. Electrophoresis profile of CHN (a) and $\mathrm{CHN}+\mathrm{LH}$ (b) cheeses during ripening (CHN: Aromatic mesophilic culture CHN-22 and LH: L. helveticus B02). 
$\beta$-casein. We observed $\gamma_{3}$-casein band fraction after 17 days of ripening, while in the cheese without the addition of an adjunct culture this fraction was evident only at 45 days of ripening. El-Soda et al. [38] found that the ability to degrade casein depended on the species: L. lactis and L. bulgaricus hydrolyzed both, $\alpha_{s 1^{-}}$ and $\beta$-casein; L. helveticus only hydrolyzed $\beta$-casein and L. acidophilus only $\alpha_{\mathrm{s} 1}$-casein.

Table 2 shows the composition and evolution of the total and individual free amino acids of $\mathrm{CHN}$ and $\mathrm{CHN}+\mathrm{LH}$ cheeses after 3, 24 and 45 days of ripening.

The individual and total free amino acid levels progressively increased in $\mathrm{CHN}$ and $\mathrm{CHN}+\mathrm{LH}$ cheeses $(P<0.05)$. However, there was no significant difference in the amount of any of the free amino acids due to the use of the adjunct culture. Glutamic acid and leucine were the free amino acids found in greater quantities in the two cheeses produced. The former is known to be a main contributor to umami taste. Glutamic acid and mineral salts were the key drivers for umami taste in Cheedar cheese according to research conducted by Andersen et al. [39]. In that work glutamic acid was equivalent to $31 \%-34 \%$ of the total amount of amino acids in Cheddar. Presently, glutamic acid was equivalent to $18 \%$ of the total amount of amino acids in Prato cheese.

Table 2. Profile of individual and total free amino acids $\left(\mathrm{mg} 100 \mathrm{~g}^{-1}\right)$ of the $\mathrm{CHN}$ and $\mathrm{CHN}+\mathrm{LH}$ cheeses at 3, 24 and 45 days of ripening.

\begin{tabular}{|c|c|c|c|c|c|c|}
\hline \multirow{2}{*}{ Amino acid } & \multicolumn{3}{|c|}{ CHN Cheese } & \multicolumn{3}{|c|}{ CHN + LH Cheese } \\
\hline & 3 & 24 & 45 & 3 & 24 & 45 \\
\hline Aspartic Acid. & $1.37^{\mathrm{b}}$ & $2.46^{\mathrm{b}}$ & $14.08^{\mathrm{a}}$ & $1.10^{\mathrm{b}}$ & $3.58^{\mathrm{b}}$ & $13.77^{\mathrm{a}}$ \\
\hline Glutamic acid & $7.40^{c}$ & $42.53^{\mathrm{b}}$ & $197.67^{\mathrm{a}}$ & $8.43^{\mathrm{c}}$ & $55.93^{\mathrm{b}}$ & $219.76^{\mathrm{a}}$ \\
\hline Serine & $2.38^{\mathrm{c}}$ & $7.28^{\mathrm{b}}$ & $23.55^{\mathrm{a}}$ & $2.81^{\mathrm{c}}$ & $15.54^{\mathrm{b}}$ & $21.26^{\mathrm{a}}$ \\
\hline Glycine & $0.83^{c}$ & $13.68^{\mathrm{b}}$ & $19.90^{\mathrm{a}}$ & $1.03^{c}$ & $7.53^{\mathrm{b}}$ & $16.74^{\mathrm{a}}$ \\
\hline Histidine & $8.16^{\mathrm{b}}$ & $12.99^{\mathrm{b}}$ & $50.53^{\mathrm{a}}$ & $8.00^{c}$ & $16.32^{\mathrm{b}}$ & $45.11^{\mathrm{a}}$ \\
\hline Arginine & $3.10^{c}$ & $12.48^{\mathrm{b}}$ & $26.86^{\mathrm{a}}$ & $1.19^{\mathrm{c}}$ & $11.75^{\mathrm{b}}$ & $21.74^{\mathrm{a}}$ \\
\hline Threonine & $2.31^{\mathrm{c}}$ & $13.81^{\mathrm{b}}$ & $28.22^{\mathrm{a}}$ & $2.99^{\mathrm{c}}$ & $16.68^{\mathrm{b}}$ & $30.20^{\mathrm{a}}$ \\
\hline Alanine & $6.84^{\mathrm{c}}$ & $16.51^{\mathrm{b}}$ & $25.02^{\mathrm{a}}$ & $7.07^{\mathrm{c}}$ & $16.87^{\mathrm{b}}$ & $25.47^{\mathrm{a}}$ \\
\hline Proline & $20.90^{c}$ & $29.90^{\mathrm{b}}$ & $41.34^{\mathrm{a}}$ & $19.22^{c}$ & $27.93^{b}$ & $44.88^{\mathrm{a}}$ \\
\hline Tyrosine & $10.77^{\mathrm{c}}$ & $23.63^{\mathrm{b}}$ & $40.04^{\mathrm{a}}$ & $9.58^{\mathrm{c}}$ & $22.46^{\mathrm{b}}$ & $38.94^{\mathrm{a}}$ \\
\hline Valine & $9.44^{c}$ & $43.62^{\mathrm{b}}$ & $79.77^{\mathrm{a}}$ & $8.43^{\mathrm{c}}$ & $42.61^{\mathrm{b}}$ & $90.10^{\mathrm{a}}$ \\
\hline Methionine & $4.15^{\mathrm{c}}$ & $11.86^{\mathrm{b}}$ & $15.90^{\mathrm{a}}$ & $4.34^{\mathrm{c}}$ & $13.20^{\mathrm{b}}$ & $18.46^{\mathrm{a}}$ \\
\hline Cystine & $9.92^{\mathrm{ab}}$ & $9.05^{\mathrm{b}}$ & $15.20^{\mathrm{a}}$ & $10.04^{\mathrm{a}}$ & $11.02^{\mathrm{a}}$ & $21.26^{\mathrm{a}}$ \\
\hline Isoleucine & $3.89^{\mathrm{c}}$ & $15.76^{\mathrm{b}}$ & $35.67^{\mathrm{a}}$ & $7.42^{\mathrm{b}}$ & $17.55^{\mathrm{b}}$ & $39.82^{\mathrm{a}}$ \\
\hline Leucine & $15.54^{\mathrm{c}}$ & $99.92^{\mathrm{b}}$ & $205.01^{\mathrm{a}}$ & $25.22^{\mathrm{c}}$ & $103.52^{\mathrm{b}}$ & $232.72^{\mathrm{a}}$ \\
\hline Phenylalanine & $10.48^{c}$ & $48.46^{\mathrm{b}}$ & $85.65^{\mathrm{a}}$ & $8.37^{\mathrm{c}}$ & $51.03^{\mathrm{b}}$ & $100.06^{\mathrm{a}}$ \\
\hline Lysine & $18.17^{\mathrm{c}}$ & $49.19^{\mathrm{b}}$ & $87.37^{\mathrm{a}}$ & $18.18^{c}$ & $51.93^{\mathrm{b}}$ & $98.01^{\mathrm{a}}$ \\
\hline Tryptophan & $12.12^{\mathrm{c}}$ & $50.66^{\mathrm{b}}$ & $93.03^{\mathrm{a}}$ & $11.78^{c}$ & $68.67^{\mathrm{b}}$ & $114.66^{\mathrm{a}}$ \\
\hline Total & $149.86^{\mathrm{c}}$ & $503.55^{\mathrm{b}}$ & $1084.87^{\mathrm{a}}$ & $147.29^{c}$ & $554.42^{\mathrm{b}}$ & $1215.04^{\mathrm{a}}$ \\
\hline
\end{tabular}

Different letters in the same row are significantly different (Tukey's test, $P<0.05)$. Abbreviations: Ac. Acid; LD: Aromatic mesophilic culture CHN-22; LH: L. helveticus B02. 
According to Kabelová et al. [3] there are distinctive taste groups of aminoacids: bitter tasting amino acids (leucine, lysine, and phenylalanine), bitter sweet amino acids (proline and valine), and salty-umami amino acids (glutamic acid and aspartic acid). In the present study, glutamic acid, arginine, glycine, aspartic acid, phenylalanine, valine, and threonine were the most evident free amino acids during the ripening period-in descending order. Their concentration increased 10 to 25 times in the 45 day period and the main ones observed corresponded to approximately $40 \%$ of the total free amino acids. However, considering the sum observed in the 45 days of ripening, the increase of free amino acids was 7.2 times for $\mathrm{CHN}$ and 8.2 times for $\mathrm{CHN}+\mathrm{LH}\left(1084\right.$ and $1215 \mathrm{mg} 100^{-1}$ of Prato cheese, respectively).

Considering the sum of Glu and Asp for CHN or CHN + LH cheeses, both of them presented $19 \%$ of these umami amino acids released by ripening. However, in absolute numbers, in a $30 \mathrm{~g}$ portion of cheese, $63 \mathrm{mg}$ and $70 \mathrm{mg}$ of theses umami amino acids were found, respectively in CHN or CHN + LH samples, and that higher quantity found in the cheese made with adjunct culture could be the reason for the taste improvement observed in the sensory test.

There are few published works on the release of free amino acids in Prato cheese. In one of the published works (in which adjunct culture was not used) an 8 -fold increase of free amino acids was achieved during ripening (60 days) with a final average value of $2.454 \mathrm{mg} 100 \mathrm{~g}^{-1}$ of total solids [37]. In the mentioned work, the main amino acids were taurine / GABA, glutamic acid, leucine, lysine, tryptophan and phenylalanine, corresponding to $62 \%$ of the total free amino acids found [37].

Moreno [36] showed an increase in the levels of total free amino acids in four commercial samples of Prato cheese (named A, B, C and D). The progressive evolution of total amino acid levels at the beginning and end of the 45 days ripening was higher for Cheese $\mathrm{D}\left(734.6\right.$ - $\left.2037.7 \mathrm{mg} 100 \mathrm{~g}^{-1}\right)$, followed by cheese C (141.7 - $\left.1240.9 \mathrm{mg} 100 \mathrm{~g}^{-1}\right), \mathrm{B}\left(127.7\right.$ - $\left.557.9 \mathrm{mg} 100 \mathrm{~g}^{-1}\right)$ and A (47.3 - 225.1 $\left.\mathrm{mg} 100 \mathrm{~g}^{-1}\right)$. The faster accumulation of free amino acids in the cheeses $\mathrm{C}$ and $\mathrm{D}$ compared to cheeses A and B was due to the autolysis of L. helveticus.

\subsection{Sensory Analysis}

Table 3 and Table 4 presents the average results obtained in the acceptability tests of $\mathrm{CHN}$ and $\mathrm{CHN}+\mathrm{LH}$ Prato cheeses at the beginning (7 days) and the end (45 days) of the ripening period and a commercial sample.

At the beginning of ripening (Table 3 ) the results showed no significant differences $(P>0.05)$ for the attribute texture among the three cheeses: $\mathrm{CHN}$ and $\mathrm{CHN}+\mathrm{LH}$ and commercial product, with the averages close to "I like it".

Cheese flavor is one of the most important criteria for product quality and consumer acceptance [39]. The three cheeses showed overall aroma and flavor differences $(P \leq 0.05)$, which showed higher means and close to "I like it" for $\mathrm{CHN}+\mathrm{LH}$ cheese. As for the appearance of CHN + LH cheese, it did not differ significantly from the $\mathrm{CHN}$ cheese. 
Table 3. Acceptability of the Prato cheese samples 7 days after production.

\begin{tabular}{ccccc}
\hline Attribute & CHN Cheese & CHN + LH Cheese & Commercial cheese & L.S.D. \\
\hline Appearance & $6.9(1.4)^{\mathrm{ab}}$ & $7.2(1.1)^{\mathrm{a}}$ & $6.5(1.7)^{\mathrm{b}}$ & 0.45 \\
Aroma & $6.5(1.5)^{\mathrm{b}}$ & $7.1(1.1)^{\mathrm{a}}$ & $6.5(1.5)^{\mathrm{b}}$ & 0.42 \\
Texture & $6.4(1.5)^{\mathrm{a}}$ & $6.8(1.4)^{\mathrm{a}}$ & $6.8(1.6)^{\mathrm{a}}$ & 0.45 \\
Flavor & $6.3(1.6)^{\mathrm{b}}$ & $7.0(1.4)^{\mathrm{a}}$ & $6.0(1.8)^{\mathrm{b}}$ & 0.50 \\
Overall Quality & $6.4(1.6)^{\mathrm{b}}$ & $7.1(1.3)^{\mathrm{a}}$ & $6.1(1.8)^{\mathrm{b}}$ & 0.49 \\
\hline
\end{tabular}

Results expressed as mean (standard deviation) from 100 evaluations. L.S.D. least significant difference at $5 \%$ significance level (Tukey test). For each attribute (line), values followed by the same letters are not statistically different from each other $P<0.05)$. Abbreviations: CHN: Aromatic mesophilic culture CHN-22; LH: L. helveticus $\mathrm{B} 02$.

Table 4. Acceptability of the Prato cheese samples 30 days after production.

\begin{tabular}{ccccc}
\hline Attribute & CHN Cheese & CHN + LH Cheese & Commercial cheese & L.S.D. \\
\hline Appearance & $7.0(1.2)^{\mathrm{b}}$ & $7.4(0.9)^{\mathrm{a}}$ & $7.2(1.2)^{\mathrm{ab}}$ & 0.33 \\
Aroma & $6.7(1.3)^{\mathrm{b}}$ & $7.1(1.1)^{\mathrm{a}}$ & $6.6(1.4)^{\mathrm{b}}$ & 0.41 \\
Texture & $7.0(1.1)^{\mathrm{a}}$ & $6.9(1.3)^{\mathrm{a}}$ & $7.1(1.2)^{\mathrm{a}}$ & 0.36 \\
Flavor & $6.7(1.4)^{\mathrm{ab}}$ & $7.1(1.2)^{\mathrm{a}}$ & $6.4(1.8)^{\mathrm{b}}$ & 0.49 \\
Overall & $6.7(1.3)^{\mathrm{b}}$ & $7.3(1.2)^{\mathrm{a}}$ & $6.5(1.6)^{\mathrm{b}}$ & 0.43 \\
Quality & & &
\end{tabular}

Results expressed as mean (standard deviation) from 100 evaluations. L.S.D. Least significant difference at $5 \%$ significance level (Tukey test). For each attribute (line), values followed by the same letters are not statistically different from each other $P<0.05)$. Abbreviations: $\mathrm{CHN}$ : Aromatic mesophilic culture $\mathrm{CHN}-22$; LH: L. helveticusB02.

At 30 days (Table 4$)$ of ripening the samples differed $(P \leq 0.05)$ in terms of overall quality, aroma and flavor, and the sample containing the adjunct culture had higher averages and ranked between "I liked it" and "I really liked it". As for appearance, there was no significant difference between the $\mathrm{CHN}+\mathrm{LH}$ cheeses and the $\mathrm{CHN}$ cheese.

Therefore, the adjunct culture L. helveticus helped to improve the sensory and overall characteristics of Prato Cheese, in terms of aroma and flavor, giving it a higher quality standard when compared to cheese prepared without this culture and a commercial brand obtained at the market.

Improvements in flavor, texture and overall impression of Prato cheese with the addition of adjunct culture ( $L$. helveticus) were observed in the work of Barros et al. [35]. Another study on Prato cheese, also with the addition of L. helveticus and L. plantarum, also reported acceptance improvements, with higher averages for the attributes flavor, texture and purchase intent in samples with the addition of L. helveticus [34].

\section{Conclusion}

The addition of Lactobacillus helveticus B02 as an adjunct culture of mesophilic aromatic culture $\mathrm{CHN}-22$ contributed to the improvement of sensory characteristics of Prato cheese, in terms of overall aroma and flavor. The electrophoretic 
profile of cheeses and total free amino acids highlighted the role of $L$. helveticus in the degradation process of caseins, particularly $\beta$-casein.

\section{Acknowledgements}

The authors are grateful to Fundação de Amparo à Pesquisa do Estado de São Paulo (FAPESP, Sao Paulo, Brazil) for financing the Project (12/10789-8) and to Coordenação de Aperfeiçoamento de Pessoal de Nível Superior (CAPES) for the postgraduate scholarship.

\section{References}

[1] Nepomuceno, R.S.C., Costa Jr, L.C.G. and Costa, R.G. (2016) ExopolysaccharideProducing Culture in the Manufacture of Prato Cheese. LWT-Food Science and Technology, 72, 383-389. https://doi.org/10.1016/j.lwt.2016.04.053

[2] Brasil (1997) Ministério da Agricultura, Pecuária e Abastecimento. Portaria N³58, De 04/09/1997 (Reference Method). Regulamento Técnico Para Fixação de Identidade e Qualidade do Queijo Prato. Diário Oficial da União, Brasília.

[3] Kabelová, I.M, Č́žková, H., Dostálek, P. and Karel, M. (2009) Determination of Free Amino Acids in Cheeses from the Czech Market. Czech Journal of Food Sciences, 27, 143-150.

[4] Andersen, L.T., Schlichtherle-Cerny, H. and Ardo, Y. (2008) Hydrophilic Di- and Tripeptides Are Not a Precondition for Savoury Flavour in Mature Cheddar Cheese. Dairy Science \& Technology, 88, 467-475. https://doi.org/10.1051/dst:2008015

[5] Cogan, T.M. (1995) Flavour Production by Dairy Starter's Cultures. Journal of Applied Bacteriology, 79, 49-64.

[6] Moreno, I., Vialta, A., Lerayer, A.L.S. and Destro, M.T. (2002). A Importância da Microbiota Adicionada e Autóctone na Maturação de Queijo Prato. Indústria de Laticínios, 7, 59-62.

[7] Antunes, A.E.C., Silva, E.R.A., Van Dender, A.G.F., Marasca, E.T.G., Moreno. I., Faria, E.V., Padula, M. and Lerayer, A.L.S. (2009) Probiotic Buttermilk-Like Fermented Milk Product Development in a Semiindustrial Scale: Physicochemical, Microbiological and Sensory Acceptability. International Journal of Dairy Technology, 62, 556-563. https://doi.org/10.1111/j.1471-0307.2009.00534.x

[8] Antunes, A.E.C., Liserre, A.M., Faria, E.V., Yotsuyanagi, K. and Lerayer, A.L.S. (2012) Análise Descritiva Quantitativa de Buttermilk Probiótico. Alimentos e Nutrição, 23, 619-629.

http://serv-bib.fcfar.unesp.br/seer/index.php/alimentos/article/viewFile/619/1822

[9] Griffiths, M.W. and Tellez, A.M. (2013) Lactobacillus Helveticus: The Proteolytic Systems. Frontiers in Microbiology, 4, 1-9. https://www.ncbi.nlm.nih.gov/pmc/articles/PMC3587842/pdf/fmicb-04-00030.pdf

[10] Giraffa, G. (2014) Lactobacillus helveticus: Importance in Food and Health. Frontiers in Microbiology, 5, 1-2. https://doi.org/10.3389/fmicb.2014.00338

[11] Von Wright, A. and Axelsson, L. (2011) Lactic Acid Bacteria: An Introduction. In: Lahtinen, S., Ouwehand, A.C., Salminen, S. and Von Wright, A., Eds., Lactic Acid Bacteria: Microbiological and Functional Aspects, Fourth Edition. CRC Press, Boca Raton, 1-15. https://doi.org/10.1201/b11503

[12] Mayo, B.D., Van Sinderen, D. and Ventura, M. (2008) Genome Analysis of Food Grade Lactic Acid-Producing Bacteria: From Basics to Applications. Current Genomics, 9, 169-183. https://doi.org/10.2174/138920208784340731 
[13] Espejo, F.J., Almécija, M.C., Guadix, A. and Guadix, E.M. (2011) Antihypertensive Peptides Found in Cheese. In: Foster, R.D., Ed., Cheese: Types, Nutrition and Consumption, Nova Science Publishers, New York, 221-245.

[14] Sadat-Mekmene, L., Genay, M., Atlan, D., Lortal, S. and Gagnaire, V. (2011) Original Features of Cell-Envelop Proteinases of Lactobacillus helveticus. A Review. International Journal of Food Microbiology, 146, 1-13. https://doi.org/10.1016/j.ijfoodmicro.2011.01.039

[15] Furtado, M.M. and Lourenço Neto, J.P.M. (1994) Tecnologia de Queijos: Manual Técnico Para a Produção Industrial de Queijos. Dipemar Ltda, São Paulo.

[16] Brasil (2006) Ministério da Agricultura, Pecuária e Abastecimento. Instrução Normativa 68 (Reference Method). Métodos Analíticos Oficiais Físico-Químicos Para Controle de Leite e Produtos Lácteos. V-Métodos Quantitativos. Diário Oficial da União, Brasília.

[17] IDF (1982) Determination of the Total Solids Content of Cheese and Processed Cheese. International Dairy Federation, Bruxelas.

[18] Acton, G.H. (1977) The Determination of Lactose in Cheese. The Australian Journal of Dairy Technology, 32, 111-114.

[19] Serres, L., Amariglio, S. and Petransxiene, D. (1973) Controle de la Qualité des Produits Laitiers. Ministère de l'Agriculture. Direction des Services Vétérinaires, Tome I, Analyse Physique et Chimique (Chimie VII-6).

[20] Horwitz, W. (1975) Official Methods of Analysis of the Association of Official Analytical Chemists. 12th Edition, Association of Official Analytical Chemists, Washington.

[21] APHA (2004) Standard Methods for the Examination of Dairy Products.

[22] IDF (1962) Determination of the Protein Total Nitrogen Content of Milk by Kjeldahl Method. International Dairy Federation, Bruxelas.

[23] Vakarelis, D.G. and Price, W.C. (1959) A Rapid Spectrophotometer Method for Measuring Cheese Ripening. Journal of Dairy Science, 42, 264-276. https://doi.org/10.3168/jds.S0022-0302(59)90562-4

[24] Aschaffenburg, R. and Drewry, J. (1959) New Procedure for the Routine Determination of the Various Non-Casein Proteins of Milk. Proceedings of the 15th International Dairy Congress, London, 1631-1637.

[25] Chaves, K.S. and Gigante, M.L. (2016) Prato Cheese as Suitable Carrier for Lactobacillus Acidophilus La5 and Bifidobacterium Bb-12. International Dairy Journal, 52, 10-18. https://doi.org/10.1016/j.idairyj.2015.08.009

[26] Andrews, A.T. (1983) Proteinases in Normal Bovine Milk and Their Action on Caseins. Journal of Dairy Research, 50, 45-55. https://doi.org/10.1017/S0022029900032519

[27] Hagen, S.R., Frost, B. and Augustin, J. (1989) Precolumn Phenylisothiocyanate Derivatization and Liquid Chromatography of Aminoacids in Food. Journal of Association Official Analytical Chemistry, 72, 912-916.

[28] White, J.A., Hart, R.J. and Fry, J.C. (1986) An Evaluation of the Waters Pico-Tag System for the Amino-Acid Analysis of Food Materials. The Journal of Automatic Chemistry, 8, 170-177.

https://www.ncbi.nlm.nih.gov/pmc/articles/PMC2547673/pdf/JAMMC-08-170.pdf https://doi.org/10.1155/S1463924686000330

[29] Meilgaard, M., Civille, G.V. and Carr, B.T. (2006) Sensory Evaluation Techniques. 4th Edition, CRC Press,Boca Raton.

[30] Brasil (2011) Ministério da Agricultura Pecuária e Abastecimento. Instrução Nor- 
mativa $\mathrm{N}^{\circ}$ 62, De 29/12/2011 (Reference Method). Regulamentos Técnicos de Produção, Identidade e Qualidade do Leite Tipo A, Leite Cru Refrigerado e Leite pasteurizado. Diário Oficial da União, Brasília. http://www.apcbrh.com.br/files/IN62.pdf

[31] Spadoti, L.M, Dornellas, J.R.F. and Roig, S.M. (2005) Avaliação Sensorial de Queijo Prato Obtido Por Modificações do Processo Tradicional de Fabricação. Ciência e Tecnologia de Alimentos, 25, 705-712. https://doi.org/10.1590/S0101-20612005000400013

[32] Brasil (1996) Regulamentos Técnicos de Identidade e Qualidade dos Produtos Lácteos. Ministério da Agricultura e do Abastecimento. Secretaria Nacional de Inspeção de Produtos de Origem Animal. Diário Oficial da União, Brasília.

http://brasil.minagri.gob.cl/wp-content/uploads/2012/08/Adjunto-n\%C2\%BA15-Po rtaria-146_96.pdf

[33] Fox, P.F. and McSweeney, P.L.H. (1998) Dairy Chemistry and Biochemistry. Blackie Academic Professional, London.

[34] Sato, R.T., Vieira, A.T.B., Camisa, J., Vianna, P.C.B. and Rensis, C.M.V.B. (2012) Assessment of Proteolysis and Sensory Characteristcs of Prato Cheese with Adjunct Culture. Semina, 33, 3143-3152.

[35] Barros, C.M.V., Cunha, C.R., Gallina, D.A., Viotto, L.A. and Viotto, W.H. (2006) Efeito do Uso de Cultura Adjunta (Lactobacillus helveticus) na Proteólise, Propriedades Viscoelásticas e Aceitação Sensorial de Queijo Prato Light. Ciência e Tecnologia de Alimentos, 26, 11-18. https://doi.org/10.1590/S0101-20612006000100003

[36] Moreno, I. (2003) Efeito da Autólise de Culturas Lácticas na Proteólise do Queijo Prato. São Paulo-Faculdade de Ciências Farmacêuticas, Universidade de São Paulo.

[37] Gorostiza, A., Cichoscki, A.J., Valduga, A.T., Valduga, B.A. and Fresno, J.M. (2004) Changes in Soluble Nitrogenous Compounds, Caseins and Free Amino Acids during Ripening of Artisanal Prato Cheese; A Brazilian Semi-Hard Cows Variety. Food Control, 85, 407-414. https://doi.org/10.1016/j.foodchem.2003.07.018

[38] El-Soda, M., Desmazeaud, M.J., Aboudonia, S., and Badran, A. (1982) Acceleration of Cheese Ripening by the Addition of Extracts from Lactobacillus Helveticus, Lactobacillus Bulgaricus and Lactobacillus Lactis to the Cheese Curd. Milchwissenschaft, 37, 325-326.

[39] Andersen, L.T., Ardo, Y. and Bredie, W.L.P. (2010) Study of Taste-Active Compounds in the Water-Soluble Extract of Mature Cheddar Cheese. International Dairy Journal, 20, 528-536. https://doi.org/10.1016/j.idairyj.2010.02.009 
Submit or recommend next manuscript to SCIRP and we will provide best service for you:

Accepting pre-submission inquiries through Email, Facebook, LinkedIn, Twitter, etc. A wide selection of journals (inclusive of 9 subjects, more than 200 journals)

Providing 24-hour high-quality service

User-friendly online submission system

Fair and swift peer-review system

Efficient typesetting and proofreading procedure

Display of the result of downloads and visits, as well as the number of cited articles Maximum dissemination of your research work

Submit your manuscript at: http://papersubmission.scirp.org/

Or contact fns@scirp.org 